ISSN:2656-4270 (Online) 1410-4466 (Print) Accredited by Ministry of Research, Technology, and Higher Education with the ranking of Sinta (S4) SK NO.28/E/KPT/2019, 26th September 2019
Buletin Penelitian Sosial Ekonomi Pertanian Fakultas Pertanian Universitas Haluoleo 2020:22(2):51-57

http://ojs.uho.ac.id/index.php/sosek

doi: http://dx.doi.org/10.37149/sosek.v22i2.13493

\title{
THE CORRELATION BETWEEN LAND OWNERSHIP STATUS, PARENTS OCCUPATION, AND FUTURE OF AGRICULTURE WITH THE YOUTH ATTITUDE WHO WORK IN AGRICULTURAL SECTOR (Case of Pamijahan Sub-District, Bogor District)
}

\author{
Yogaprasta Adi Nugraha ${ }^{1^{*}}$, Layung Paramesti Martha ${ }^{1^{*}}$ \\ ${ }^{1}$ Pakuan University \\ ${ }^{*}$ Corresponding author : yogaprasta_adinugraha@unpak.ac.id
}

To cite this article:

Nugraha, Y., \& Martha, L. (2020). The Correlation between Land Ownership Status, Parents Livelihood, and Future of Agriculture with the Youth Attitude who Work in Agricultural Sector (Case of Pamijahan Sub-District, Bogor District). Buletin Penelitian Sosial Ekonomi Pertanian Fakultas Pertanian Universitas Haluoleo, $22(2), 51$ 57. doi:http://dx.doi.org/10.37149/bpsosek.v22i2.13493

Received: August 13, 2020; Accepted: September 23, 2020; Published: September 27, 2020

\begin{abstract}
The objectives of this research were (1) identifying parents' land ownership status in Pamijahan Sub-District, Bogor District, (2) Identifying parents' occupation in Pamijahan Sub-District, Bogor District, (3) Identifying the youth preference towards residency place in the future, (4) analyzing the correlation between land ownership status, parents' occupation, youth future residency preference and rural-youth attitude towards agricultural sector. This research was performed in Ciasmara Village, Pamijahan Sub-District, Bogor District, from 2019 to 2020, using quantitative method and chi-square to identify the association between land ownership status, parents' occupation, youth future residency preference and rural-youth attitude towards agricultural sector. This research found that parents' occupation and youth future preference towards residency place were correlated with rural-youth attitude towards agricultural sector.
\end{abstract}

Keywords: future residency; land; parents' occupation; rural-youth attitude towards agriculture; sector.

\section{INTRODUCTION}

The agricultural sector is one of the leading sectors that contributes significantly to Indonesia's national income. Agricultural sector is not only a major contributor to national income, but also one of the sectors which is capable of absorbing labor. According to Supriyati (2010), the agricultural sector in Indonesia has proven to have an important role in the national economic development. The agricultural sector in Indonesia plays a role as (1) provider of food for the Indonesian people, (2) provider of basic raw materials for the Industrial and Service sector, (3) the agricultural sector can generate or save foreign exchange from exports of agricultural products. Meanwhile, White (2018) also stated that the agricultural sector, especially small-scale agriculture, has an important role in absorbing labor, especially young workers in rural areas. Human resources, in this case agricultural labor, have an important position capable of encouraging or turning the agricultural sector into a leading sector capable of being the basis for Indonesia's economic development. Agricultural labor is the main driver of agricultural activities and economic development in rural areas. However, based on Nugraha, (2012), there are unfavorable facts related to agricultural labor in Indonesia where 35.5 percent of agricultural workers have no primary education and 46.2 percent have graduated from elementary school. This indicates that workers who have higher education are less interested in being involved in working in the agricultural sector and this can have an impact on agricultural management, especially in this uncertain situation. Apart from the low level of education of agricultural workers in Indonesia, the agricultural sector in Indonesia also encounters a situation of reluctance of rural youth to work in the agricultural sector. Several studies have shown that youth are starting to show reluctance to work in the agricultural sector (White, 2018); (Nugraha \& Herawati, 2015); Valdiani et al., (2017). In fact, according to Nugraha (2012), 70 percent of farmers in 
Indonesia are over 50 years old. This condition is a clear illustration that there is no regeneration of young workers in the agricultural sector. Many youths come from farming families in agricultural production centers who do not work in the agricultural sector and prefer sectors other than agriculture.

The low participation of rural youth in the agricultural sector is a separate problem for the sustainability of the agricultural sector in the future. This condition is even more worrying considering that Indonesia will enter a period of Demographic Surplus, a condition in which the proportion of people of productive age is higher than the non-productive age, so it is feared that agriculture will be increasingly abandoned by the youth. Several previous studies conducted by White, (2018); (Nugraha, 2012); (Nugraha \& Herawati, 2015); and Nugraha \& Supriatna, (2020), have shown that there were many factors that cause youths to not be interested in working in the agricultural sector, including (1) lack of access to land or the length of time that parents hand over the land management authority to their children, (2) agriculture is considered economically unprofitable or more profitable for the non-agricultural sector, (3) an image of agriculture that is considered not prestigious or dirty and is close to poverty in the village, and (4) schools tend to frame jobs in villages negatively and have no future. The involvement of youth in the employment in the agricultural sector is closely related to the extent to which the environment around them supports working in the agricultural sector or not.

The most basic and important thing in agricultural activities is access or availability of land. A study conducted by Harahap \& Ambarwati (2015) found that there was a decrease in the number of pure working farmers and an increase in the number of agricultural laborers who were not farming, while according to Nugraha \& Herawati (2015), currently control of agricultural land in the village was no longer evenly distributed. The land is relatively owned by large farmers in the village or already owned by urban people who no longer live in the village. The low number of farmers in the village who own land has an impact on changes in the types of farmers, who are initially categorized as landowning farmers, then turn into pure cultivators, and in the end, when small land farmers lose their cultivated land, they will become agricultural laborers. The less land owned by farmers will make the attachment of farmers or the community in the village lower and it is feared that it will make small farmers in the village more vulnerable to change. Based on this situation, this research intended to focus on examining the extent to which land access, parents' occupation, and youth residential preferences in the future are able to shape the interest of rural youth to work in the agricultural sector. In more detail, this research intended to answer several research questions below, including: (1) What is the ownership status of the parents' rice fields in Ciasmara Village, Pamijahan Sub-District, Bogor District? (2) What are the parents' occupation of young people in Ciasmara Village, Pamijahan SubDistrict, Bogor District? (3) Are youth in Ciasmara Village still interested in living in the village? (4) Is there a relationship between the status of rice field ownership, the type of parents' occupation, and plans to live in the future with the attitude of youth to work in the agricultural sector? Based on the formulation of the problems above, this research aimed to: (1) describe the ownership status of the rice fields of young people in Ciasmara Village, Pamijahan Sub-District, Bogor District, (2) describe the occupation of the youth parents in Ciasmara Village, Pamijahan Sub-District, Bogor District, (3) describe the future residential plans for the youth in Ciasmara Village, (4) analyze the relationship between the ownership status of rice fields, the type of parents' occupation, and plans to live in the future with the youth's interest in working in the agricultural sector.

\section{MATERIALS AND METHODS}

This research was conducted from September 2019 to February 2020 focusing on land access, parents' occupation, and youth residential preferences. This research was conducted in Ciasmara Village, Pamijahan Sub-District in Bogor District. Ciasmara Village was chosen because it had several considerations, as stated by Jayawinangun \& Nugraha (2018); Nugraha \& Nugroho (2019); Nugraha \& Supriatna (2020b), Ciasmara Village is one of the rice barns in Bogor District. The village still preserves the earth's alms culture and is located near the center of the garment/textile industry. A total of 129 youths in Ciasmara Village were selected as the research samples using purposive sampling approach. The data analysis used in this study were (1) descriptive analysis using tables, frequencies, and average scores to get a picture of the ownership status of the land, the occupation of the parents, the plan to live in the future, and attitudes of youth to work in the agricultural sector, (2) Inference analysis used in this study is the Chi-Square analysis to determine the relationship or association between land ownership status, parent's occupation, and future living plans with youth attitudes towards employment in the agricultural sector. 


\section{RESULTS AND DISCUSSION}

\section{Land Ownership Status}

Land plays an important role in the sustainability of occupations in the agricultural sector (White, 2018); (Harahap \& Ambarwati, 2015). In addition, land is one of the prerequisites for agricultural activities, more than just availability, access to land is also an important factor that can make job in the agricultural world works. In this study, land access was seen from the point of view of the land ownership status of the young people in Ciasmara Village, Pamijahan Sub-District, Bogor District.

Table 1. Parents' land ownership status

\begin{tabular}{ccc}
\hline Status Ownership & $\begin{array}{c}\text { Frequency } \\
\text { (Person) }\end{array}$ & $\begin{array}{c}\text { Percent } \\
(\%)\end{array}$ \\
\hline Own Rice Fields & 89 & 68.99 \\
Do not have rice fields & 40 & 31.01 \\
\hline Total & 129 & 100 \\
\hline
\end{tabular}

Based on Table 1, information was obtained that as many as 89 respondents in Ciasmara Village or around 68.99 percent of research respondents said that their parents owned rice fields, while about 40 respondents or about 31.01 respondents said that their parents did not own rice fields. This condition illustrates that the rice fields in Ciasmara Village, Pamijahan Sub-District, Bogor District were still owned by the residents in the village. This finding is supported by an explanation from the village secretary of Ciasmara who said that more than 85 percent of farmers in Ciasmara village still cultivated their own rice fields, not other people's. The high number of farmers who still owned their own rice fields is an important factor for maintaining the sustainability of agriculture in Ciasmara village. According to (Nugraha \& Supriatna, 2020a), farmers who own their own rice fields or land have "sovereignty" to manage their fields. In fact, according to Harahap \& Ambarwati (2015), farmers who own agricultural land can choose what rice seeds they want to plant, the type of fertilizer, and what medicine they want to use. Moreover, farmers who own agricultural land can independently determine when to harvest. According to the Village Secretary, 90 percent of the rice fields in Ciasmara Village were productive and irrigated rice fields. This condition makes rice fields as important asset which are still owned by people in the village itself. In only one village, large farmers owned rice fields.

\section{Parents' occupation}

The main occupation of parents in Ciasmara Village as referred to in this study was type of the youth parents' occupation of the Ciasmara village which spend the most time. In this study, the types of work were divided into two, namely agricultural and non-agricultural work. The parents' occupation has an important position in passing on agricultural values. According to Nugraha \& Supriatna (2020b) and Nugraha \& Herawati (2015), families working in the agricultural sector have a great opportunity to pass the agricultural values to their children either in the form of involvement as a workforce in the family or in daily conversations at home.

Table 2. Main occupations of parents

\begin{tabular}{ccc}
\hline Occupations of Parents & $\begin{array}{c}\text { Frequency } \\
\text { (Person) }\end{array}$ & $\begin{array}{c}\text { Percent } \\
(\%)\end{array}$ \\
\hline Farming & 65 & 50.4 \\
Non - Farming & 64 & 49.6 \\
\hline Total & 129 & 100 \\
\hline
\end{tabular}

Table 2 shows that 50.4 percent of youth in the study sample, or about 65 youth had parents who worked as farmers. Meanwhile, around 49.5 percent of youth or about 64 youth had parents who worked in the non-agricultural sector, such as becoming traders, factory workers, government officials, teachers, and others. Ciasmara Village is one of the villages that has become a granary for the Bogor District. Based on the results of interviews with the Chairperson of the Asmara Jaya Gapoktan, Pak Manji, the majority of Ciasmara villagers worked as farmers, but sometimes agriculture is not used as the main occupation sector. They had several other alternative jobs, such as teachers, village officials, traders, and owning shops. According to Nugraha \& Herawati (2015), farmers in 
villages generally have other job alternatives to reduce the risk of income uncertainty from the agricultural sector.

\section{Future Residential Plans}

In this study, future residential plans were defined as housing plans for young people in Ciasmara Village when they grow up. The future residential plan of the youth in Ciasmara Village is very important to be studied because it is difficult for the regeneration of agriculture in the village to occur if the youth decide to move outside the village and sell their agricultural land. According to Nugraha \& Herawati (2015), there are several patterns of youth migration in the village. There are youths who are permanent migration which means working and living outside the village, their circular migration who works outside the village but at certain times, such as during the big harvest or when the growing season. There are also young people who live permanently in the village but work outside the village.

Table 3. Future residence plans

\begin{tabular}{ccc}
\hline Stay Plan & $\begin{array}{c}\text { Frequency } \\
\text { (Person) }\end{array}$ & $\begin{array}{c}\text { Percent } \\
(\%)\end{array}$ \\
\hline Within Ciasmara Village & 110 & 85.3 \\
Outside Ciasmara Village & 19 & 14.7 \\
\hline Total & 129 & 100 \\
\hline
\end{tabular}

According to Table 3, information can be obtained that 85.3 percent of youth or about 110 youth who became the research respondents said that they wanted to stay in Ciasmara Village. Meanwhile, around 14.7 percent or about 19 youth did not want to stay in the village. This condition illustrates that Ciasmara Village is still considered comfortable by the village youth, so they still plan to live in Ciasmara Village even though they are married later. Several studies have shown that youth in rural areas initially intended to temporarily migrate out of the village but after marriage they will return to the village, as stated by Supriatna \& Nugraha (2020), that most of the old farmers in the village Ciasmara had migrated first when they were young working around Jabodetabek, but during the 1998 monetary crisis, they returned to Ciasmara Village and worked as farmers. The phenomenon of high youth interest in staying in Ciasmara village showed that the village was still considered a proper place to live. Another reason why the youth still wanted to stay in the village according to (Nugraha \& Siregar, 2018) is that the village was still the place that provides the most effective social safety net system. The tradition of helping neighbors, the tradition of involving neighbors in planting and harvesting activities, and the ease of borrowing from a nearby shop are some of the "systems" that are considered to be able to help villagers from vulnerability. This condition is often encountered and makes youths still have a high interest in living in the village.

\section{Relationship between Parents 'Land Ownership Status, Parents' Occupation, and Future Residential Plans and Youth Attitudes.}

Attitude is a person's tendency to act towards an object of attitude (Nugraha \& Supriatna, 2020b). In this study, attitude is defined as a youth's tendency to act towards employment in the agricultural sector. Hypothetically, there are many factors that can influence the attitude of youth to be interested or not interested in working in the agricultural sector, both internally from within the youth and externally from outside the youth. According to (White, 2018), there are at least four main factors that influence youth interest in working in the agricultural sector, namely access to land, youth social system, prestige, and agricultural image. This research will try to focus on how the ownership status of rice fields, the occupation of parents, and the preferences of where young people live when they are married.

\section{Relationship of Land Ownership Status and Youth Attitudes}

Access to agricultural land in this study was limited to the status of the parents' agricultural land ownership. According to (Harahap \& Ambarwati, 2015), farmers 'access to land ownership can increase farmers' interest in working in the agricultural sector. In this study, the status of parental land ownership was considered to be related to youth attitudes towards employment in the agricultural sector.

There is no real difference between youth who come from families who have their own land status and youth who come from families who do not own land and are equally less interested in working in the agricultural sector. This is because youth whose parents own rice fields also cannot access their agricultural land directly, they have to wait until a certain period of time and they can own 
the land from their parents. In addition, the land belonging to their parents had to be shared with other family members. The same thing was found in research conducted by (Nugraha \& Herawati, 2015) and (White, 2018), where youth in the village had to wait until they finally had their parents' rice fields. Sometimes, parents do not want to immediately give the ownership of their rice fields to their children when they are young because they are afraid that they will be sold so that they cannot farm again in the future.

Table 4. Relationship between land ownership status and attitudes

\begin{tabular}{|c|c|c|c|c|}
\hline Attitude Aspects & Land Access & $\begin{array}{l}\text { Frequency } \\
\text { (Person) }\end{array}$ & Average & Sig $^{*}$ \\
\hline Cognitive & $\begin{array}{l}\text { Own Rice Fields } \\
\text { Do not have rice fields }\end{array}$ & $\begin{array}{l}89 \\
40\end{array}$ & $\begin{array}{l}2.7545 \\
2.7795\end{array}$ & 0.711 \\
\hline Affective & $\begin{array}{c}\text { Own Rice Fields } \\
\text { Do not have rice fields }\end{array}$ & $\begin{array}{l}89 \\
40 \\
\end{array}$ & $\begin{array}{l}2.6112 \\
2.6200\end{array}$ & 0.924 \\
\hline Psychomotor & $\begin{array}{c}\text { Own Rice Fields } \\
\text { Do not have rice fields }\end{array}$ & $\begin{array}{l}89 \\
40\end{array}$ & $\begin{array}{l}2.2145 \\
2.2108\end{array}$ & 0.973 \\
\hline Attitude & $\begin{array}{l}\text { Own Rice Fields } \\
\text { Do not have rice fields }\end{array}$ & $\begin{array}{l}89 \\
40\end{array}$ & $\begin{array}{l}2.5266 \\
2.5370\end{array}$ & 0.876 \\
\hline
\end{tabular}

Information: * Significant < 0.05; ** Very Significant $<0.01$

\section{Relationship between Parents' Occupation and Youth Attitudes towards Work in the Agricultural Sector}

The occupation of parents has a big influence on how a child or young person sees a job Nugraha (2012); (Nugraha \& Supriatna, 2020a). In this study, the occupation of parents was considered to be related to youth attitudes towards the employment in the agricultural sector.

Table 5. Relationship between parents' work status and attitudes

\begin{tabular}{|c|c|c|c|c|}
\hline Attitude Aspects & Parents' Occupation & $\begin{array}{c}\text { Frequency } \\
\text { (Person) }\end{array}$ & Average & Sig* $^{*}$ \\
\hline Cognitive & Farming & 65 & 2.6818 & $0.009^{\star *}$ \\
\hline & Not Farming & 64 & 2.8439 & \\
\hline Affective & $\begin{array}{c}\text { Farming } \\
\text { Not Farming }\end{array}$ & $\begin{array}{l}65 \\
64\end{array}$ & $\begin{array}{l}2.5477 \\
2.6812\end{array}$ & 0.116 \\
\hline Psychomotor & $\begin{array}{c}\text { Farming } \\
\text { Not Farming }\end{array}$ & $\begin{array}{l}65 \\
64 \\
\end{array}$ & $\begin{array}{l}2.1443 \\
2.2834 \\
\end{array}$ & 0.178 \\
\hline Attitude & $\begin{array}{c}\text { Farming } \\
\text { Not Farming }\end{array}$ & $\begin{array}{l}65 \\
64\end{array}$ & $\begin{array}{l}2.4578 \\
2.6030\end{array}$ & $0.017^{*}$ \\
\hline
\end{tabular}

Information: * Significant $<0.05 ;{ }^{* *}$ Very Significant $<0.01$

This study found that the type of parental occupation has a significant relationship with a significance value of 0.017 . This means that there are differences in the attitudes between youths whose parents work as farmers and youths whose parents do not farm. From the average score, it can be seen that youth who came from farming families tended to have a negative attitude towards the employment in the agricultural sector. This is different from the attitude of youth whose parents did not work in the agricultural sector. This is because youth whose parents worked in the agricultural sector tended to negatively share the agriculture with their children such as agriculture that often fails to harvest, drought, and the price of grain which is paid cheaply. This condition unwittingly affects the subconscious of young farmers' willingness to work in the agricultural sector. As stated by (Valdiani et al., 2017), parents have a very important role in the construction or deconstruction of the sacred value of agriculture. Nugraha (2012) in his study also found that parents, especially fathers, tend to talk about agriculture with negative messages and they often forbid their children to work in the agricultural sector. These negative agricultural messages are usually conveyed in a different arena such as at home watching television or helping their parents work in the fields.

This study found that parents who worked as farmers and owned agricultural land suggested that their children learn to farm but did not make agriculture as their main job. For them, it is better to work on the other sectors and work in agricultural sector as a side job. Meanwhile, youths whose parents were farmers but did not own land, such as Pak Usup (50) who manages the Perhutani land, himself encouraged their children to work in other sectors besides the agricultural sector because they wanted to see their children to be much better than themselves. There was also Mrs. Icah (55) 
who said that she was more supportive of her child to pursue the highest education so that she can get a better job, because the child's job is to learn properly in order to get a decent job in the future.

\section{The Relationship between Future Residential Preference and Attitudes toward Agriculture}

The future residential preference of youth in this study was defined as the location of future residence desired by the youth in the village, whether they were more interested in living in Ciasmara Village or outside Ciasmara Village. Youth preference for future residential is a variable that is relatively rarely studied in understanding youth preferences for working in the agricultural sector. Nugraha \& Supriatna, (2020a) in their research found that most of the people who farmed in Ciasmara village when they were young used to work outside Ciasmara Village until certain conditions they decided to return to work in Ciasmara Village because of several considerations, including the village which is considered capable of providing socio-economic security.

Table 6. Relationship between future residence and attitudes toward agriculture

\begin{tabular}{|c|c|c|c|c|}
\hline Attitude Aspects & Future Living Plans & $\begin{array}{c}\text { Frequency } \\
\text { (Person) }\end{array}$ & Average & $\mathrm{Sig}^{*}$ \\
\hline Cognitive & Outside Ciasmara Village & 19 & 2.6263 & 0.069 \\
\hline Affective & $\begin{array}{l}\text { Within Ciasmara Village } \\
\text { Outside Ciasmara Village }\end{array}$ & $\begin{array}{c}110 \\
19 \\
110\end{array}$ & $\begin{array}{l}2.7857 \\
2.3368 \\
26618\end{array}$ & $0.006^{* *}$ \\
\hline Psychomotor & $\begin{array}{l}\text { Outside Ciasmara Village } \\
\text { Within Ciasmara Village }\end{array}$ & $\begin{array}{c}19 \\
110\end{array}$ & $\begin{array}{l}2.1726 \\
2.2204\end{array}$ & 0.744 \\
\hline Attitude & $\begin{array}{l}\text { Outside Ciasmara Village } \\
\text { Within Ciasmara Village }\end{array}$ & $\begin{array}{c}19 \\
110\end{array}$ & $\begin{array}{l}2.3795 \\
2.5558\end{array}$ & $0.040^{*}$ \\
\hline
\end{tabular}

Information: * Significant $<0.05 ;{ }^{* *}$ Very Significant $<0.01$

As can be seen, there was a significant difference in the attitude between youth who plan to live outside Ciasmara Village and youth who plan to live in Ciasmara Village with a significance value of 0.040 . Meanwhile, when viewed from the average score, youth who tended to plan to stay in Ciasmara Village in the future had a more positive attitude towards the employment in the agricultural sector than youth who plan to live outside Ciasmara Village. If revealed in more detail, these differences in attitudes occurred because of differences in youth affections. Youth who planned to stay in Ciasmara village had a positive level of affection while youth who planned to leave Ciasmara village had negative attitudes towards the employment in the agricultural sector. Young people who were interested in staying in Ciasmara village were generally those who came from "middle" farmers who already had their own rice fields, so they did not feel the need to leave Ciasmara Village because everything is relatively available in the village. As found by Nugraha \& Siregar (2018) who stated that rural communities have a tendency to stay in the village because the village is considered capable of providing social and economic security, and there are also sources of non-formal access to finance that do not pose a risk, such as food stalls and close family. Meanwhile, it is very different if they are in cities, most youth do not have social networks when they are in a vulnerable condition as well as they do not have economic support and social safety nets.

\section{CONCLUSIONS}

Approximately 68.99 percent of the study respondents said that their parents own rice fields, while 31.01 respondents said that their parents did not own rice fields. As much as 50.4 percent of the youth in the study sample had their parents working as farmers. Meanwhile, around 49.5 percent of their parents worked in the non-agricultural sector, such as becoming traders, factory workers, government officials, teachers, and others. Furthermore, 85.3 percent of the youth who became the survey respondents said that they wanted to stay in Ciasmara village. Meanwhile, around 14.7 percent. This condition illustrates that Ciasmara Village is still considered comfortable by the village youth, so they still planned to live in Ciasmara Village even though they are married later. This study found that youth attitudes towards employment in the agricultural sector had a significant relationship with the variable of parents' employment and the variable of youth housing plans in the future. This study found that youth preference in rural areas has a strong relationship with youth interest in working in the agricultural sector. 


\section{ACKNOWLEDGMENTS}

The author would like to thank the Ministry of Research, Technology and Higher Education and the Ministry of Education and Culture for providing research grants until this research was carried out. Acknowledgments are also conveyed to other parties concerned for the assistance provided to the author.

\section{REFERENCES}

Harahap, R. A., \& Ambarwati, A. (2015). Tanah Untuk Penggarap? Penguasaan Tanah dan Struktur Agraris di Beberapa Desa Penghasil Padi. Jurnal Analisis Sosial Akatiga, 19(1), 1-30.

Jayawinangun, R., \& Nugraha, Y. A. (2018). Penggunaan Internet Dan Media Sosial Orang Muda Di Pedesaan. Wahana, 24(2), 1-14.

Nugraha, Y. A. (2012). Hubungan antara Orang Tua, Teman Sepermainan, dan Media Massa dengan Sikap Pemuda terhadap Pekerjaan di Sektor Pertanian (Kasus Desa Cipendawa dan Desa Sukatani, Kecamatan Pacet, Kabupaten Cianjur). Bogor Agricultural University.

Nugraha, Y. A., \& Herawati, R. (2015). Menguak realitas orang muda sektor pertanian di perdesaan. Seri Penelitian Akatiga, 19(1).

Nugraha, Y. A., \& Nugroho, D. R. (2019). Rural Youth Behavior In Watching Television (Case Study Rural Youth in Ciasmara Village Pamijahan Sub-District, Bogor Regency). Jhss (Journal of Humanities and Social Studies), 3(1), 32-36. https://doi.org/10.33751/jhss.v3i1.1098

Nugraha, Y. A., \& Siregar, M. R. . (2018). The Role Of Local Loan Institution In Providing Safety Net In Rural Area. Jhss (Journal of Humanities and Social Studies), 2(1), 1-6. https://doi.org/10.33751/jhss.v2i1.813

Nugraha, Y. A., \& Supriatna, R. A. (2020a). Peran Teman Sepermainan Dalam Membentuk Sikap Pemuda Pedesaan Terhadap Pekerjaan Di Sektor Pertanian Padi ( Kasus Pemuda di Desa Ciasmara , Kecamatan Pamijahan Kabupaten Bogor ). Jurnal Ilmiah Agribisnis, 5(1), 1-10.

Nugraha, Y. A., \& Supriatna, R. A. (2020b). Pola Komunikasi Ritual Orang Tua-Anak Dalam Pewarisan Pengetahuan Dan Afeksi Terkait Pekerjaan Di Sektor Pertanian Padi. Commed: Jurnal Komunikasi Dan Media, 4(2), 208. https://doi.org/10.33884/commed.v4i2.1591

Supriatna, R. A., \& Nugraha, Y. A. (2020). Menguak Realitas Praktik Sedekah Bumi di Desa Ciasmara Kecamatan Pamijahan Kabupaten Bogor. Jurnal Penelitian Sosial Ilmu Komunikasi, 2(1), 43-59.

Supriyati. (2010). The Dynamic of Agricultural Employment Economy: Problems and Policy Development Strategy pertanian dalam pembangunan perekonomian secara keseluruhan , terutama pada 1964 ). Keberhasilan pembangunan pereko. Analisis Kebijakan Pertanian, $8(1), 49-65$.

Valdiani, D., Nugraha, Y. A., \& Siregar, M. R. . (2017). Attendance Of Mass Media And Parents In Defining The Value Of Agriculture In The Eyes Of Rural (Case Study of Rural Youth at Horticulture Center in Cianjur Regency). Jhss (Journal of Humanities and Social Studies), 1(1), 28-34. https://doi.org/10.33751/jhss.v1i1.370

White, B. (2018). Marx and Chayanov at the margins: understanding agrarian change in Java. The Journal of Peasant Studies, 45(5-6), 1108-1126. https://doi.org/10.1080/03066150.2017.1419191 